\title{
Hypokalemic metabolic alkalosis in an adolescent female: Questions
}

\author{
Elif Benderlioğlu ${ }^{1}$ (D) Hakan Öğütlü ${ }^{2}$ - Alkım Öden Akman ${ }^{3}$ - Demet Taş ${ }^{4}$. \\ Aylin Irmak Kuruç ${ }^{5}$ Sare Gülfem Özlü ${ }^{6} \cdot$ Umut Selda Bayrakçi ${ }^{6}$
}

Received: 21 January 2021 / Accepted: 3 February 2021 / Published online: 23 February 2021

(C) IPNA 2021

Keywords Adolescent $\cdot$ Hypokalemic metabolic alkalosis $\cdot$ Amenorrhea

\section{Case summary}

A 16-year-old girl was referred to our pediatric nephrology outpatient clinic for further evaluation of hypokalemic metabolic alkalosis. She had applied to her family physician due to amenorrhea for the last 3 months. At the first evaluation, her past medical history was unremarkable; she did not describe muscle cramps, diarrhea, or polyuria; and there was no history of medication use. She had her menarche at the age of about 12 years. Her complaints started 3 months ago with daily vomiting after every meal, and she lost almost $12 \mathrm{~kg}$ in this period. There was no parental consanguinity, and she did not have a family history of kidney disease.

On admission, physical examination was normal except for body weight; she was $42 \mathrm{~kg}(<3$ rd percentile), and her body

The answers to these questions can be found at https://oi.org/10.1007/ s00467-021-04989-x.

Elif Benderlioğlu

elifbenderlioglu@gmail.com

1 Department of General Pediatrics, Ankara City Hospital, Ankara, Turkey

2 Department of Child and Adolescent Psychiatry, Ankara City Hospital, Ankara, Turkey

3 Department of Adolescent Medicine, Ankara City Hospital, Ankara, Turkey

4 Faculty of Medicine, Department of Adolescent Medicine, Ankara City Hospital, Ankara Yıldırım Beyazıt University, Ankara, Turkey

5 Department of General Pediatrics, Ankara City Hospital, Ankara, Turkey

6 Department of Pediatric Nephrology, Ankara City Hospital, Ankara Yıldırım Beyazıt University, Ankara, Turkey mass index (BMI) was $16 \mathrm{~kg} / \mathrm{m}^{2}(<5$ th percentile, underweight). Her height was $162 \mathrm{~cm}$ (50th percentile). Her ideal weight for height was $55 \mathrm{~kg}$ (her weight/ideal weight for height percentage was 75\%). Blood pressure was 100/70 $\mathrm{mmHg}$ (50th percentile). Motor, mental, and pubertal development was normal for her age.

Laboratory investigations revealed hypokalemic metabolic alkalosis; potassium was $2.6 \mathrm{mEq} / \mathrm{L}$, bicarbonate was $33 \mathrm{mEq} / \mathrm{L}$, and $\mathrm{pH}$ was 7.52 . Serum creatinine was $0.66 \mathrm{mg} / \mathrm{dL}$ and serum electrolytes other than potassium were in the normal range: Sodium was $137 \mathrm{mEq} / \mathrm{L}$ (132-146 mg/dL), calcium was $9.1 \mathrm{mg} / \mathrm{dL}(9.1-10.3$ $\mathrm{mg} / \mathrm{dL})$, phosphorus was $3.4 \mathrm{mg} / \mathrm{dL}(2.9-4.8 \mathrm{mg} / \mathrm{dL})$, magnesium was $2.1 \mathrm{mg} / \mathrm{dL}(1.3-2.7 \mathrm{mg} / \mathrm{dL})$, and chloride was $101 \mathrm{mEq} / \mathrm{L}(99-109 \mathrm{mEq} / \mathrm{L})$. Serum albumin level was also normal $(48 \mathrm{~g} / \mathrm{L})$.

She did not have hematuria, proteinuria, or pyuria; urine culture was sterile. Plasma renin activity and serum aldosterone levels were normal. Urinary calcium, potassium, sodium, and chloride excretions were normal. The kidney and the bladder ultrasound was also normal.

\section{Questions}

1. What is the most likely diagnosis in this patient?

2. How should this patient be further managed?

Publisher's note Springer Nature remains neutral with regard to jurisdictional claims in published maps and institutional affiliations. 